\title{
Profil Usaha Industri Kecil Tahu dan Tempe "Makmur Jaya" di Kecamatan Denpasar Barat, Kota Denpasar
}

\author{
KENTAK YULI AMBARA, I NYOMAN GEDE USTRIYANA, \\ I KETUT RANTAU
}

Program Studi Agribisnis, Fakultas Pertanian, Universitas Udayana

Jl. PB. Sudirman Denpasar 80232

Email: iamambara14@gmail.com

gede_ustriyana@unud.ac.id

\begin{abstract}
Profile of Small Industries Tofu and Tempeh "Makmur Jaya" in The District West Of Denpasar, The City Of Denpasar
\end{abstract}

This study aimed to determine the profile of industrial businesses of tofu and tempeh (Makmur Jaya), which included the availability of raw and auxiliary materials, production systems, production processes, types and quantities of production, costs of production, revenue, and marketing channels of small industries in the District of West Denpasar, Denpasar City. The data collected in this study were primary and secondary data, and method of collecting data.

Profile of small industries of tofu and tempeh is a general overview of a business, in this case is the business of tofu and tempeh. The source of capital used by Makmur Jaya in producing tofu and tempeh was its own capital for business sustainability. The average amount of soybean raw materials required by Makmur Jaya in one production process for the manufacture of tofu and tempeh, namely, a total of 1.75 quintals per day to produce tofu and tempeh. Of which $75 \mathrm{~kg}$ of soybeans were used for making tofu, while the remaining $100 \mathrm{~kg}$ for making tempeh. The average cost of production facilities issued by Makmur Jaya for producing tofu and tempeh for one time production process was an average of Rp. 59,762,083 per month. Makmur Jaya generally marketed their products to markets. The revenue generated by Makmur Jaya industrial business of tofu and tempeh was $\mathrm{Rp} 39,237,917$ per month.

Keywords: tofu and tempeh, profiles, marketing channel, revenue

\section{Pendahuluan}

\subsection{Latar Belakang}

Tahu dan tempe sudah akrab di lidah orang Indonesia sejak lama. Makanan hasil variasi olahan kacang kedelai ini pun menjadi makanan yang populer karena harganya yang relatif terjangkau untuk dikonsumsi masyarakatdari berbagai lapisan, mulai dari masyarakat kelas bawah, masyarakat kelas menengah, hingga masyarakat kelas atas. Bahkan seperti diberitakan, tahu dan tempe mulai digemari beberapa 
negara tetangga seperti Malaysia, Jepang, dan lain-lain karena rasanya yang nikmat serta bergizi tinggi. Hal yang menarik dari keberadaan industri tahu dan tempe adalah skala industrinya yang kebanyakan masih berupa industri kecil dan menengah yang berproduksi dengan metode tradisional, padahal daya beli masyarakat untuk produk ini relatif tinggi. Meskipun didalam persaingan dengan makanan luar negeri, tahu dan tempe tetap eksis di pasaran. Pasar untuk produk ini pun tergolong cukup luas, namun biasanya konsumen tahu dan tempe merupakan kalangan menengah ke bawah (Anonim, 2011).

Industri skala rumah tangga yang mengembangkan usaha tahu tempe di kota Denpasar dan sekitarnya mencapai lebih dari 210 orang, setiap harinya memanfaatkan kedelai sebagai bahan baku rata-rata $100-150 \mathrm{~kg} /$ orang. Persediaan bahan baku kedelai sebenarnya tidak masalah, cuma harganya cukup mahal, selama ini masih menyiasatinya dengan mengecilkan ukuran tidak menaikkan harga.

Industri Makmur Jaya yang berada di kota Denpasar Barat adalah salah satu perusahaan yang bergerak pada industri tahu dan tempe, dengan menggunakan kedelai sebagai bahan baku produksinya. Industri Makmur Jaya melayani permintaan di sekitar wilayah Kota Denpasar Barat dan di daerah pasar Kuta. Pemenuhan kebutuhan permintaan yang semakin besar maka industri Makmur Jaya biasanya dalam sekali memesan bahan baku kedelai sejumlah dua ton, yang dipergunakan kurang lebih selama tiga minggu. Dalam sekali produksi biasanya perusahaan menggunakan kurang lebih $100 \mathrm{~kg}$ kedelai yang nantinya diolah menjadi tahu dan tempe. Persediaan bahan baku tersebut ada kalanya tidak dapat mencukupi kebutuhan pelanggan yang terus meningkat sehingga perusahaan melakukan pemesanan kembali yang menimbulkan adanya biaya tambahan, sebaliknya pada saat tertentu industri tahu tempe Makmur Jaya mengalami kelebihan stok bahan baku, hal ini disebabkan berkurangnya permintaan terhadap tahu dan tempe dari konsumen. Selain itu keterlambatan persediaan bahan baku di distributor juga menghambat proses produksi tempe tahu industri Makmur Jaya.

Kebutuhan tahu dan tempe di Provinsi Bali masih kurang aman dan masyarakat Bali sangat khawatir mengenai kenaikan harga kedele yang melambung tinggi yang berhimbas pada pasokan tahu dan tempe. Menurut Pak Sundoyo pemilik usaha tahu dan tempe mengatakan di tahun 2015 harga kedelai Rp 9.000,- dan hari ini harga kedelai mencapai Rp 11.000,-. Masih bisa mencukupi kebutuhan masyarakat Bali. Selain itu, bahwa pangsa pasar dalam negeri akan terus tumbuh seiring dengan peningkatan permintaan akan konsumsi penduduk. Harga kedelai yang antraktif menjadi perangsang bagi petani untuk berproduksi, disisi lain menjadi kendala bagi industri berbahan baku kedelai.

Hal inilah yang melatar belakangi penelitian "Profil Usaha Industri Kecil Tahu dan Tempe "Makmur Jaya" di Kecamatan Denpasar Barat, Kota Denpasar" untuk mengetahui profil usaha industri kecil, sistem pemasaran, dan pendapatannya dalam usaha tahu dan tempe. 


\subsection{Rumusan Masalah}

1. Bagaimana profil usaha industri kecil tahu dan tempe "Makmur Jaya" di Kecamatan Denpasar Barat, Kota Denpasar?

2. Bagaimana pendapatan usaha industri kecil tahu dan tempe di Kecamatan Denpasar Barat, Kota Denpasar?

3. Bagaimana saluran pemasaran tahu dan tempe di Kecamatan Denpasar Barat, Kota Denpasar?

\subsection{Tujuan Penelitian}

Adapun tujuan dari penelitian ini untuk mengetahui :

1. Profil usaha industri kecil tahu dan tempe "Makmur Jaya" di Kecamatan Denpasar Barat, Kota Denpasar.

2. Besarnya pendapatan usaha industri kecil tahu dan tempe.

3. Saluran pemasaran tahu dan tempe tersebut.

\section{Metode Penelitian}

\subsection{Lokasi dan Waktu Penelitian}

Lokasi penelitian ini di Jalan Imam Bonjol Gg Nyuhsawit No. 14, Denpasar, Bali. Adapun waktu penelitian dilaksanakan dari bulan Agustus-September 2016. Dipilihnya daerah ini dilakukan secara sengaja (purposive sampling).Metode purposive yaitu suatu metode penentuan daerah penelitian yang sebelumnya ditentukan atas pertimbangan-pertimbangan tertentu. Dasar pertimbangan di daerah ini sebagai berikut :

1. Usaha ini telah berdiri dari tahun 1989 sampai sekarang tahun 2017 dimana usaha berlokasi di daerah Imam Bonjol, Denpasar.

2. Belum pernah dilakukan penelitian dengan topik yang serupa sebelumnya pada daerah ini.

\subsection{Jenis dan Sumber Data}

Berdasarkan jenis data yang dipergunakan, maka dalam penelitian ini akan digunakan data kuantitatif dan kualitatif. Menurut Kuncoro (2003), data kuantitaif yaitu data yang dapat diukur dengan angka, sedangkan data kualitatif adalah data yang tidak dapat diukur dengan angka. Data kuantitatif dalam penelitian ini meliputi ketersediaan bahan baku, sistem produksi, proses produksi, jenis produksi dan biaya produksi, sistem pemasaran, dan pendapatan usaha home industry tahu dan tempe. Data kualitatif dalam penelitian ini adalah data yang berasal dari hasil wawancara.

\subsection{Metode Pengumpulan Data}

Penelitian ini menggunakan dua cara dalam mengumpulkan data, sebagai berikut:

1. Metode wawancara 
Wawancara dilakukan dengan mmelakukan survei lapangan ke usaha home industry di Jalan Imam Bonjol untuk mendapatkan data-data yang diperlukan dalam penelitian ini.

2. Studi pustaka

Studi pustaka adalah pengumpulan data-data baik dari buku, jurnal, artikel, atau lembaga/instansi yang akan menunjang penelitian ini.

\subsection{Variabel dan Pengukuran Data}

1. Profil usaha industri kecil tahu dan tempe.

a. Ketersediaan bahan baku

Komponen yang diukur adalah jumlah bahan baku, yaitu banyaknya kedelai yang diibutuhkan setiap bulan.

b. Sistem produksi

Sistem produksi ini mengambil bahan baku dan mengubahnya menjadi produk jadi yang diperoleh dari suplayer.

c. Proses produksi

Untuk mengetahui proses produksi dilakukan dengan mengidentifikasi jenis kegiatan pada usaha industri kecil tahu dan tempe.

d. Jenis produksi

- Untuk mengetahui jenis produksi dilakukan dengan mengidentifikasi hasil produksi fisik yang diperoleh dari usaha industri kecil tahu dan tempe.

- Jumlah produksi adalah jumlah produk yang dihasilkan setiap unit usaha dalam hal ini usaha perorang yang dinyatakan dalam buah.

\section{Pendapatan}

Pendapatan usaha industri kecil tahu dan tempe adalah pendapatan bersih yang diterima perorang dinyatakan rupiah. Pendapatan ini dihitung dengan cara mengurangkan penerimaan dengan pengeluaran dan dinyatakan dalam rupiah.

3. Pemasaran yaitu dengan mengidentifikasi saluran pemasaran hasil produksi fisik.

\subsection{Analisis Data}

1. Untuk mengetahui profil usaha industri kecil tahu dan tempe dianalisis dengan menggunakan metode deskriptif yaitu data yang diperoleh kemudian diolah, disusun, dan disajikan dalam bentuk tabel atau bagan yang sesuai, kemudian diinterpretasikan dan diambil kesimpulan.

2. Untuk mengetahui pendapatan dilakukan analisis biaya dan pendapatan dengan formulasi (Soekartawi, 1995:58).

$$
\mathrm{Pd}=\mathrm{TR}-\mathrm{TC}
$$

$$
\begin{aligned}
\text { Keterangan: } & \mathrm{Pd} \\
\mathrm{TR} & =\text { Total Pendapatan }(\mathrm{Rp} / \mathrm{bulan}) \\
\mathrm{TC} & =\text { Total Biaya }(\mathrm{Rp} / \mathrm{bulan})
\end{aligned}
$$

Dari rumus diatas dimana total penerimaan, merupakan perkalian antara produksi yang diperoleh dengan harga jual: 


$$
\begin{array}{rll} 
& \mathrm{TR}=\mathrm{Y} . \mathrm{Py} \\
\text { Keterangan: } & \mathrm{TR} & =\text { Total Penerimaan }(\mathrm{Rp} / \mathrm{bulan}) \\
\mathrm{Y} & =\text { Produksi tahu dan tempe }(\mathrm{biji} / \mathrm{bulan}) \\
\mathrm{Py} & =\text { Harga Y (Rp/biji tahu dan Rp/biji tempe) }
\end{array}
$$

Untuk menghitung total biaya digunakan formulasi.

$$
\mathrm{TC}=\mathrm{VC}+\mathrm{FC}
$$

Keterangan: $\mathrm{TC}=$ Total Biaya $(\mathrm{Rp} / \mathrm{bulan})$

$\mathrm{VC} \quad=$ Biaya Variabel (Rp/bulan)

$\mathrm{FC} \quad=$ Biaya Tetap (Rp/bulan)

Penelitian ini pendapatan dihitung dalam 1 bulan saja selama jangka waktu penelitian yaitu pada bulan Agustus 2016

3. Upah tenaga kerja dihitung dengan analisis finansial. Misalnya jumlah tenaga kerja yang dipakai 100 HKSP (Hari Kerja Setara Pria) dengan upah Rp $50.000,00 /$ hari, maka biaya tenaga kerja adalah $100 \times \mathrm{Rp} 50.000,00=\mathrm{Rp}$ 5.000.000,00. Bila diantara 100 HKSP tersebut, 25 HKSP diantaranya adalah tenaga kerja keluarga, maka nilai upah yang dihitung hanya upah tenaga kerja dari luar keluarga saja sebesar 75 HKSP tersebut (Soekartawi, 1995: 57).

4. Pemasaran hasil industri kecil tahu dan tempe dilakukan dengan mengidentifikasi saluran pemasaran kemudian dianalisis dengan menggunakan metode deskritif.

\section{Hasil Dan Pembahasan}

\subsection{Profil}

Profil usaha industri kecil tahu dan tempe merupakan gambaran umum mengenai suatu usaha, dalam hal ini adalah usaha tahu dan tempe. profil ini akan dapat diketahui pemodalan usaha, ketersediaan bahan baku, sistem produksi, proses produksi, jenis produksi, biaya produksi, saluran pemasaran, dan pendapatan dalam proses keberlangsungan usaha. Sumber modal yang digunakan Makmur Jaya dalam memproduksi tahu dan tempe merupakan modal sendiri untuk keberlangsungan usahanya.

Ketersediaan bahan baku merupakan hal yang paling utama dalam menjalankan suatu usaha. Jika ketersediaan bahan baku terbatas maka usaha tersebut tidak bisa dilakukan dengan baik dan berkesinambungan, bahkan usaha tersebut dapat terhenti. Selain itu, perlu pula diperhatikan ketersediaan bahan penujang lainnya.

Rata-rata jumlah bahan baku kedelai yang dibutuhkan oleh bapak Sundoyo dalam satu kali proses produksi untuk pembuatan tahu dan tempe yaitu, sebanyak 1,75 kwintal kedelai per hari untuk memproduksi tahu dan tempe. Perbandingan kedelai tahu dan tempe yaitu $75 \mathrm{~kg}$ kedelai untuk membuat tahu sedangkan $100 \mathrm{~kg}$ lagi untuk pembuatan tempe, seperti yang terlihat pada Tabel 1. 
Tabel 1.

Jumlah Penggunaan Bahan baku dan Bahan Penolong Pengolahan Tahu dan Tempe di Makmur Jaya (Sekali Produksi atau Sehari)

\begin{tabular}{clcr}
\hline \multirow{2}{*}{ NO } & \multirow{2}{*}{ JENIS BAHAN BAKU } & \multicolumn{2}{c}{ JUMLAH } \\
\cline { 3 - 4 } & & PENGGUNAAN & \multicolumn{1}{c}{ NILAI } \\
\hline 1 & Kedelai & $175 \mathrm{~kg}$ & 1.225 .000 \\
2 & Cuka & $2 \mathrm{~L}$ & 30.000 \\
3 & Ragi & 62,5 ons & 3.750 \\
4 & Plastik 1,5kg \& 0,5kg & 3 pack & 47.000 \\
5 & Kayu Bakar & 1 kali produksi & 100.000 \\
\hline & JUMLAH & & 1.405 .750 \\
\hline
\end{tabular}

Industri tahu dan tempe Makmur Jaya ini patut untuk diusahakan dan terus dikembangkan. Hal ini didukung oleh ketersediaan bahan baku yang tersedia secara lokal. Berdasarkan data dari yang di dapat bahwa industri tahu dan tempe Makmur Jaya ini membeli bahan baku untuk memproduksi tahu dan tempe di UD. Inti Sari di sekitaran Ubung. Makmur Jaya ini setiap bulannya membeli kedelai di UD. Inti sari sebanyak 5,25 ton/bulan untuk kebutuhan selama 1 bulan.

Suatu perekonomian perusahaan menyediakan produk dan jasa, keduanya diproduksi oleh sistem produksi yang menggunakan mesin, energi, modal, dan tenaga kerja. Sistem produksi ini mengambil bahan baku dan mengubahnya menjadi produk jadi. Produksi membutuhkan bahan baku dan energi yang diperoleh dari sumber daya alamiah, dalam hal ini juga termasuk proses manufakturing yakni proses yang mngubah bahan baku menjadi barang jadi (Musselman dan Jackson, 1989: 324).

Industri Makmur Jaya dalam memproduksi tahu dan tempe dilakukan setiap hari oleh pekerja. Karyawan Makmur Jaya bekerja setiap harinya dan tidak ada libur sama sekali kecuali karyawan sakit akan dicarikan pekerja harian atau pemilik akan turun langsung untuk memproduksi tahu dan tempe, sedangkan hari raya idul fitri karyawan mendapatkan libur dua minggu dan pemilik akan mencari penggantinya agar usaha industri tahu dan tempe tetap berjalan. Rata-rata kerja karyawan bekerja dengan waktu kerja sembilan jam per hari.

Makmur Jaya memiliki tiga karyawan dimana masing-masing karyawannya bertugas membuat tahu, tempe, dan menjual hasil produksinya ke pasar. Jumlah tahu dan tempe yang diproduksi oleh Makmur Jaya sebanyak 3.600 tahu dan 1000 tempe per hari atau sekali proses produksi, terlihat pada Tabel 2. Harga tahu adalah Rp 500,00/biji, satu bungkus tahu berisi 10 tahu dan harga tempe adalah Rp 1.500/biji. Nilai penjualan yang diperoleh Makmur Jaya sebesar Rp 3.300.000,00 per hari. Produksi tahu dan tempe yang dihasilkan oleh Makmur Jaya ternyata masih memiliki kualitas yang lebih baik dibandingkan dengan produsen tahu dan tempe yang lainnya karena yang lainnya menjual dengan ukuran yang lebih kecil. 
Tabel 2.

Jumlah Produksi yang Dihasilkan Makmur Jaya (per hari)

\begin{tabular}{clcc}
\hline No. & \multicolumn{1}{c}{ Produksi } & Kedelai (kg) & Hasil (biji) \\
\hline 1 & Tahu & 75 & 3.600 \\
2 & Tempe & 100 & 1.000 \\
\hline Jumlah & & 175 & 4.600 \\
\hline
\end{tabular}

Pada Tabel 3 dimana biaya penyusutan alat pada usaha industri tahu dan tempe yang dikeluarkan Makmur Jaya yaitu sebesar Rp 1.089.583,00 per bulan. Besarnya nilai penyusutan untuk masing-masing alat tergantung pada frekuensi pemakaian, ketelitian dalam pemakaian alat, dan kualitas alat.

Tabel 3.

Rata-rata Jumlah Pemeliharaan dan Investaris Alat Usaha Makmur Jaya perbulan

\begin{tabular}{rlrr}
\hline \multirow{2}{*}{ No. } & \multicolumn{1}{c}{ Jenis (unit) } & \multicolumn{2}{c}{ Jumlah } \\
\cline { 3 - 4 } & & Unit & Nilai (Rp) \\
\hline A & Pemeliharaan Bangunan & 1 & 166.667 \\
2 & Sewa Lahan & 1 & 375.000 \\
\hline & Pemeliharaan Rumah Produksi & & 541.667 \\
\hline B & Inventaris Alat & 1 & 25.000 \\
1 & Cetakan Tahu & 2 & 133.333 \\
2 & Mesin Giling & 1 & 41.667 \\
3 & Kipas Angin & 2 & 50.000 \\
4 & Tungku & 1 & 41.667 \\
5 & Meja Kayu & 1 & 15.000 \\
6 & Penyaringan & 2 & 1.667 \\
7 & Pisau & 1 & 750.000 \\
8 & Mobil & 10 & 31.250 \\
9 & Bak Penampungan & & 1.089 .583 \\
\hline & & Jumlah & \\
\hline & & & 1.631 .250 \\
\hline
\end{tabular}


Usaha industri tahu dan tempe Makmur Jaya ini merupakan industri yang masih berskala kecil dan merupakan industri rumah tangga. Oleh karena itu hampir semua kegiatan dilakukan oleh tenaga kerja rumah tangga yang terdiri atas suami, istri, anak, dan dibantu oleh tenaga kerja dari luar keluarga.

Pada usaha industri tahu dan tempe ini, tenaga kerja diupah dengan sistem bulanan. Biaya-biaya tersebut dikeluarkan untuk megupah tenaga kerja di Makmur Jaya, pada kegiatan pembuatan tahu karyawan menerima upah sebesar Rp 125.000/hari, pembuat tempe sebesar Rp 120.000/hari dan karyawan yang menjual di pasar di upah sebesar Rp 100.000/hari. Perbedaan tersebut dikarenakan proses kerja dari pembuatan tahu dan tempe berbeda. Pada proses pembuatan tempe jauh lebih mudah dibandingkan dengan proses pembuatan tahu. Sedangkan pada proses pembuatan tahu memerlukan tenaga yang lebih besar dalam hal menyaring ampas kedelai dan mencetak tahu. Oleh karena itu, upah karyawan yang membuat tahu lebih besar Rp 5.000 di bandingkan dengan upah karywan yang membuat tempe.

Tabel 4.

Biaya Pengeluaran Produksi Pembuatan Tahu dan Tempe Bulan Agustus-September 2016

\begin{tabular}{|c|l|r|}
\hline \multirow{2}{*}{ No. } & \multicolumn{1}{|c|}{ Jenis Biaya } & \multicolumn{1}{|c|}{ Nilai } \\
\cline { 3 - 3 } & & \multicolumn{1}{|c|}{ Rp } \\
\hline I & Bahan Baku dan Bahan Penolong & 42.172 .500 \\
& a. Kedelai & 36.750 .000 \\
& b. Cuka & 900.000 \\
& c. Ragi & 112.500 \\
& d. Plastik & 1.410 .000 \\
& e. Kayu Bakar @ 4X Pengambilan & 3.000 .000 \\
\hline II & Penyusutan Peralatan & 1.089 .583 \\
\hline III & Tenaga Kerja & 10.350 .000 \\
& a. Pembuat tahu & 3.750 .000 \\
& b. Pembuat tempe & 3.600 .000 \\
& c. Penjual dipasar & 3.000 .000 \\
\hline IV & Pemasaran (Angkutan) & 4.500 .000 \\
\hline V & Iuran & 450.000 \\
\hline \multirow{2}{*}{ Total } & 58.562 .083 \\
\hline
\end{tabular}

Berdasarkan Tabel 4 dapat dilihat biaya sarana produksi terdiri atas biaya bahan baku. Biaya bahan baku dan bahan penolong yaitu biaya pembelian kedelai, 
biaya pembelian cuka, biaya pembelian ragi, biaya pembelian plastik, dan biaya pembelian kayu bakar. Rata-rata biaya sarana produksi yang dikeluarkan Makmur Jaya untuk memproduksi tahu dan tempe untuk satu kali proses produksi yaitu ratarata sebesar Rp1.405.750,00 per hari. Jadi biaya per bulannya Makmur Jaya memproduksi tahu dan tempe sebesar Rp 42.172.500,00 per bulan.

\subsection{Pendapatan}

Adapun besarnya penerimaan usaha industri tahu dan tempe selama satu bulan sebesar Rp. 99.000.000,00 (tabel 5), yang diperoleh dari penjualan produk Makmur Jaya seperti tahu dan tempe. Pada tabel 5.5 total biaya yang dikeluarkan selama satu bulan dari (30 kali proses produksi) sebesar Rp. 55.562.083,00. Biaya tersebut adalah biaya bahan baku dan bahan penolong, biaya tenaga kerja, biaya pemasaran, biaya penyusutan alat, biaya listrik dan air, dan biaya iuran.

Pendapatan usaha industri tahu dan tempe diperoleh dari selisih antara penerimaan dengan biaya-biaya yang digunakan. Besarnya penerimaan per bulan yang diperoleh Makmur Jaya sebesar Rp. 99.000.000,00 (belum memperhitungkan penggunaan bahan baku, tenaga kerja, pemasaran, penyusutan alat, listrik dan air, dan iuran). Jika penggunaan bahan baku, tenaga kerja, pemasaran, penyusutan alat, listrik dan air, dan iuran diperhitungkan maka besarnya pendapatan usaha industri Makmur Jaya lebih besar pendapatan yang diterima sebesar Rp. 43.437.917,00.

\section{Tabel 5.}

Pendapatan Usaha Industri Tahu dan Tempe Selama Satu Bulan.

\begin{tabular}{clr}
\hline No. & \multicolumn{1}{c}{ Uraian } & \multicolumn{1}{c}{ Jumlah (Rp) } \\
\hline 1 & Penerimaan & 99.000 .000 \\
\hline 2 & Total Biaya & \\
& 1. Biaya Variabel & 42.172 .500 \\
& a. Bahan Baku\& Bahan Penolong & 10.350 .000 \\
& b. Tenaga Kerja & 4.500 .000 \\
& c. Pemasaran (Angkutan) & \\
& 2. Biaya Tetap & 1.089 .583 \\
& a. Penyusutan Alat & 1.200 .000 \\
& b. Listrik & 450.000 \\
& c. Iuran & 39.237 .917 \\
\hline 3 & Pendapatan &
\end{tabular}




\subsection{Saluran Pemasaran}

Makmur Jaya merupakan pihak pertama dari alur pemasaran. proses pemasaran, Makmur Jaya sebagai produsen langsung menjual produk yang dihasilkannya, baik di pasar, melalui pedagang gorengan, pedagang siomay, pedagang sayur keliling, maupun langsung ke tangan konsumen dengan cara berjualan sendiri di pasar. Tahu dan tempe yang dijual oleh Makmur Jaya ada yang tidak mengalami proses pengolahan lebih lanjut untuk sampai ke tangan konsumen, dan ada yang mengalami proses pengolahan lebih lanjut sebelum sampai ke tangan konsumen, seperti diolah menjadi tahu goreng dan tahu siomay.

Makmur Jaya melakukan penjualan di rumah, di pasar dan melalui pedagangpedagang. Makmur Jaya melakukan pengiriman hasil produksi dari rumah ke pasar dari pukul 04.00-14.00. Makmur Jaya mengangkut hasil produksi ke pasar, menggunakan kendaraan roda empat (mobil pickup). Sistem pembayaran yang dilakukan pada pegawai di pasar dengan pihak pembeli (konsumen) yaitu tunai.

\section{Kesimpulan Dan Saran}

\subsection{Kesimpulan}

Berdasarkan hasil analisis dan pembahasan yang telah diuraikan sebelumnya, maka dapat ditarik kesimpulan sebagai berikut.

1. Industri tahu dan tempe merupakan usaha perorangan atau usaha rumah tangga. Sumber modal yang digunakan Makmur Jaya dalam memproduksi tahu dan tempe merupakan modal sendiri untuk keberlangsungan usahanya. Industri Makmur Jaya dalam memproduksi tahu dan tempe sebanyak 3.600 tahu, 1.000 tempe. Total biaya yang dikeluarkan selama satu bulan Agustus 2016 dari 30 kali proses produksi sebesar Rp 59.762.083,00.

2. Pendapatan yang diperoleh oleh Makmur Jaya dari usaha industri tahu dan tempe sebesar Rp 39.237.917 per bulan.

3. Makmur Jaya pada umumnya menjual produknya ke pasar tradisional dan sistem pembayaran tunai.

\subsection{Saran}

Dari hasil penelitian yang dilakukan di Kecamatan Denpasar Barat, Kota Denpasar pada usaha industri tahu dan tempe di Makmur Jaya maka dapat disarankan;

1. Pendapatan dari produksi tahu dan tempe ini per bulan cukup tinggi ( $R p$ 39.237.917). hal ini dapat menjadi bahan informasi bagi generasi muda atau para pihak yang berminat dalam usaha produksi tahu dan tempe. Pemerintah daerah hendaknya melakukan pembinaan dengan memberikan dana dan memberikan pelatihan agar usaha industri tahu dan tempe ini bisa dikelola dengan baik.

2. Penelitian ini hanya dalam kurun 1 bulan, tidak terlihat fluktuasi produksi kedelai jangka waktu yang lebih lama, dan daya saing serta potensi pengembangan industri kecil tahu dan tempe di kota Denpasar. 


\section{Daftar Pustaka}

Anonim, 2011. Industri Tahu dan Tempe. Diakses (Online). http://hanageoedu.blogspot.co.id/2011/12/industri-tahu-dan-tempe.html

Anonim, 2012. Ketersediaan Tahu Tempe di Bali Masih Aman. Diakses (Online). http://beritadewata.com/Ekonomi-dan-Bisnis/Ekonomi-dan

Bisnis/Ketersediaan-tahu-tempe-di-bali-masih-aman.html.

Anonim, 2013. Bali Sangat Tergantung Kedelai Impor. Diakses (Online). http://www.antarabali.com/berita/43186/bali-sangat-tergantung-kedelai-impor.

Kusuma, Leo. 2012. Kisruh Harga Komoditi Kedelai. Diakses (Online).(http://leo4kusuma.blogspot.com/2012/07/mengenai-kisruh-hargakomoditi-kedelai.html, diakses 24 January 2016).

Kuncoro, Mudrajad. 2003. Metode Riset untuk Bisnis dan Ekonomi. Penerbit Erlangga.Ciracas, Jakarta.

Kuncoro, Mudrajad. 2007. Ekonomika Industri Indonesia.

Soekartawi. 1995. Analisis Usaha Tani. Universitas Indonesia Press. Jakarta.

Soekartawi. 2001. Agribisnis Teori dan Aplikasinya. PT. Raja Grafindo Persada. Jakarta.

Untung Susma Nuryadi. 2005. Profil Usaha Industri Kerajinan Serabut Kelapa di Desa Bagik Papan, Kecamatan Pringgabaya, Lombok Timur.

Venom A. Musselman dan John H. Jakson. 1989. Ekonomi Perusahaan (KonsepKonsep dan Praktek Sejaman). Jakarta : Erlangga. 